\title{
Raising awareness for sustainability in basic design
}

\author{
D. G. Ozer ${ }^{1}$, B. Satici ${ }^{1}$, B. O. Turan ${ }^{2} \&$ M. Soygenis ${ }^{3}$ \\ ${ }^{1}$ Department of Architecture, Istanbul Aydin University, Turkey \\ ${ }^{2}$ Department of Informatics, Mimar Sinan Fine Arts University, Turkey \\ ${ }^{3}$ Department of Architecture, Yildiz Technical University, Turkey
}

\begin{abstract}
This study is conducted within the Architecture Department Basic Design II course in 2011-2012 spring semester, aiming to raise awareness from the early stages of architectural education, within an ecological context with an environmentally conscious and responsible approach. Besides the conventional agenda of basic design education, a comparative study has been conducted with a test group being aware of sustainability issues, and the control group who follows the routine.

In order to introduce sustainability issues and ecological awareness to the control group of students for the first time, seminars on active and passive concepts are given, working on their projects are encouraged. Especially passive concepts such as orientation, material usage, recycling and reusing of rain and waste water, energy conservation and use of alternative energy sources are introduced as fundamentals. For the comparative study, both groups will be followed in the process with weekly exercises and the final work will be evaluated via questionnaires.

Keywords: basic design education, sustainability in design, ecological awareness, house architecture.
\end{abstract}

\section{Introduction}

Rapidly increased architectural concerns and design problems on sustainable design, force architectural students to learn, understand and integrate more data in an architectural context. Many studies have been conducted in order to integrate sustainable design into education at undergraduate or graduate level. 
Unfortunately, the educational problem has neither been studied in the first year level, nor been fully focused on by educators.

Therefore aims and expected outcomes;

- Raising sustainable design consciousness among basic design students,

- Raising awareness for environmental protection among basic design students,

- Making interdisciplinary discussions via house designs,

- Making exercises on sustainable concepts besides the basic concepts of house architecture.

\section{Architectural design education and basic design}

Architectural design education is a whole with architectural design studio courses and theoretical courses supporting them. In the first year of the education, basic design studio is the fundamental course to start the process. The main purpose of basic design studio courses is to teach "design language" by introducing students to two and three-dimensional thinking skills, and to produce high quality spaces, mass and order using this language [1]. In the first semester, the primary objective is to introduce abstract thinking and formal analysis techniques, and the secondary objective is to introduce space concepts which is the basic architectural problem. For the second semester focusing on space generation, three dimensional design and generation techniques are introduced.

Formal architectural education covers theoretical and practical courses which the candidate needs to complete. The architectural design education is the most dominant part of this structure where students experience designing in studios.

Defined as "studying space for a talented person", the architectural design studio is a doing/undoing/experiencing space for showing off creativity in architectural design education. Koester [2] defines the active learning space of a studio as an inspiring/creative experience that is also adored by students.

In his book "Design Studio", Schön [3] has pointed out that novice designers are not fully experienced in problem solving skills, and the reason is the misunderstanding of discrepancies between thought and actions. Schön [4] notifies the "reflection in action" theory, pointing out that basic design knowledge can only be obtained by "doing". Therefore all theoretical information should be integrated to design studio by doing/undoing/ experiencing.

\subsection{Introducing sustainability to basic design education}

Architectural practice has produced, especially in the last 20 years, new discourses in different areas. Largely shaped by the discourses of technology, new innovative developments put forward the area of architectural education as well as the area of architecture. Throughout the architectural education, basic design studio is the starting point for introducing the architectural concepts and space generation. One of the most important concepts to be introduced is "sustainability" in education and practice of architecture. 
In order to educate future generations of architects in the context of ever increasing environmental problems addressing built environment, above issues should be brought up in architectural education agenda; sustainable environmental design concepts should efficiently be integrated to design education process [5]. In his book "Designing with Nature", Yeang [6] states that architectural education should be reconsidered on the viewpoints of "ecology" and "environmental biology", its "traditional" standpoint should be revised according to ecological design approach. Unfortunately, "conventional design education ignoring environmental design issues" is still adopted today and unconscious architects are raised; moreover, the educators have not exhibited an appropriate manner to keep up with technology. Koester [2], at the end of his studies throughout the entire architectural education, argues that sustainability issues should be adopted as the method to build up the best design studio education.

Many studies have been conducted in the education literature from undergradute level to graduate level in architectural education. These include such studies as ecological studio integration [7-10], sustainable environmental design studio [11], ecological awareness workshops [12] and environmental design education studies $[13,14]$. The common theme in these works has been integration of sustainability issues to architectural education and raising awareness among students.

Therefore in accordance with these studies, a study has been conducted within the basic design studio process, introducing sustainable design issues and being aware of environmental problems and ecological concepts. In order to achieve this integration, the facts that should be introduced to design studio environment are:

- Energy/ecology/sustainability concepts and their use in architecture,

- Raising awareness about environmental problems and introducing sustainable architecture.

\section{Method of the study}

In order to implement a comparative study in basic design studio, two distinct groups are specified. Both are given the same problem of a house design with full technical drawing details, models and presentations throughout the semester. Since the aim of the study is to introduce sustainability issues into basic design education and to raise awareness, a test group is specified to introduce the new concepts. Near the end of the semester a seminar is given to this group on sustainability and energy efficient ecological design. Students were asked to work on their projects concentrating on this issues a few weeks more. A control group is specified in order to see comparative results. At the end of the semester, both groups' projects are reviewed and a questionnaire is evaluated. 


\section{Case study: sustainable house project in basic design}

\subsection{The problem: house design}

This exercise is implemented in the 2011-2012 spring semester which is 16 weeks long. The conventional theme of the studio work is to design a $150 \mathrm{~m}^{2}$ single house, concentrating on functional schemes, basic furnishings, user needs, activities and spatial arrangements. In the first quarter, basic elements of the house spaces are taught and were asked to be measured and drawn. These include (1) Living Room: sofa, dining table, chairs, TV unit (2) Kitchen: refrigerator, sink, appliances, oven, countertop and table (3) Bathroom: washbasin, toilet and shower (4) Bedroom: double bed, single bed, gardrobe, dresser, toilet table. In the second quarter, students start to develop their spaces separately with the help of technical drawings and modular models. In the third and fourth quarter, students start to design their homes with models and technical drawings as a whole. Each week, each student's work is criticized by the tutor to be developed further.

Additionally, every week a group of 4 students are asked to present a house project of well known architects with its 1/50 model. We believe that "learning by doing" is exercised in these presentations, since some of them presented conventional single houses and some presented ecological housing concepts with active and passive solutions.

\subsection{Introducing sustainability}

Towards the end of the semester a seminar is given to test group students on green architecture, and asked them to review their projects on these issues. The seminar topics were:

- Environmental issues and ecological environment

- Global warming and its effects on our world,

- Environmental problems and buildings, architects' role,

- Green architecture, zero energy buildings,

- Renewable energy sources and their use in buildings

- Sun Path diagram

- Basic Issues on ecological concepts and their use in winter/summer, day/night,

- Overall design criteria

- Case studies.

The seminar is told to students with basic words, and the concepts are presented in a simple way keeping in mind that the students are novice designers and very new to these concepts. The seminar at first didn't make much sense, many question marks hung over. Later on, when the students have started to use and practice them in their projects, they have understood it better and their awareness is raised. 
Basic ecological design concepts and their seasonal and daily use throughout the year is explained and asked for integration to their projects, as shown in table 1. The seminar is focused on energy gains, shading elements, heating, ventilating and air conditioning.

Table 1: Basic ecological design concepts and their seasonal and daily use throughout the year.

\begin{tabular}{|c|c|c|c|}
\hline Winter Morning & Winter Night & Summer Morning & Summer Night \\
\hline \multicolumn{4}{|l|}{ Energy gains } \\
\hline $\begin{array}{l}\text { Use of south facade } \\
\text { to maximize solar } \\
\text { gains }\end{array}$ & $\begin{array}{l}\text { Covering window } \\
\text { surfaces with } \\
\text { isolated shutters in } \\
\text { order to prevent heat } \\
\text { loses }\end{array}$ & $\begin{array}{l}\text { In order to keep } \\
\text { night cooling, } \\
\text { southern windows } \\
\text { and shades are } \\
\text { closed, sun cannot } \\
\text { penetrate inside }\end{array}$ & $\begin{array}{c}\text { In order to make use } \\
\text { of night breezes all } \\
\text { windows are left open, } \\
\text { liveable spaces in } \\
\text { northern side }\end{array}$ \\
\hline
\end{tabular}

Shading elements

\begin{tabular}{|c|c|c|c|}
\hline $\begin{array}{c}\text { There is no need for } \\
\text { shading elements for } \\
\text { maximizing solar } \\
\text { gains }\end{array}$ & $\begin{array}{c}\text { All window surfaces } \\
\text { are covered to } \\
\text { prevent heat loses }\end{array}$ & $\begin{array}{c}\text { For south facade } \\
\text { horizontal shading } \\
\text { elements, for east } \\
\text { and west facade } \\
\text { vertical shading } \\
\text { elements are used. }\end{array}$ & $\begin{array}{c}\text { To welcome night } \\
\text { breezes all surfaces } \\
\text { are left open. }\end{array}$ \\
& & & \\
\hline
\end{tabular}

Heating

\begin{tabular}{|c|c|c|c|}
\hline $\begin{array}{c}\text { Maximizing solar } \\
\text { gains from south } \\
\text { facade and use of } \\
\text { trombe walls }\end{array}$ & $\begin{array}{c}\text { Hot morning heat } \\
\text { and stored thermal } \\
\text { mass heat is used }\end{array}$ & - & \\
\hline
\end{tabular}

Ventilation

\begin{tabular}{|c|c|c|c|}
\hline $\begin{array}{c}\text { Solar chimneys is } \\
\text { used. }\end{array}$ & $\begin{array}{c}\text { Cross ventilation and } \\
\text { roof-top windows } \\
\text { are used }\end{array}$ & $\begin{array}{c}\text { Cross ventilation and } \\
\text { roof-top windows are } \\
\text { used }\end{array}$ \\
\hline
\end{tabular}

Air conditioning

\begin{tabular}{|c|c|c|c|}
\hline- & - & $\begin{array}{c}\text { Using cool air that is } \\
\text { stored at night }\end{array}$ & $\begin{array}{c}\text { Getting cool air inside } \\
\text { by opening windows }\end{array}$ \\
\hline
\end{tabular}

\subsection{Student works}

Students are evaluated according to the criteria at table 2. Architectural Criteria include functional use, zoning, architectural aesthetics, use of scenery, whereas Ecological Criteria include orientation, energy efficiency, comfort zones, solar and wind energy use, recycling, water management, materials, and shading elements.

\subsubsection{Test group design process}

Section 6 students are specified to be the test group. Besides the common agenda, as mentioned before, a sustainable design seminar is given to them in 
week 13. In weeks 14 and 15, the designs are criticized with a sustainable architectural viewpoint. Control group students are also followed in order to make a comparison with the test group at the end of the semester.

Table 2: Architectural and ecological design criteria to evaluate the students.

\begin{tabular}{|c|c|c|}
\hline \multirow{6}{*}{ 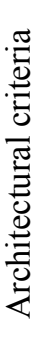 } & Functional Use & $\begin{array}{l}\text { Daily spaces } \\
\text { Nightly spaces }\end{array}$ \\
\hline & Zoning & Common spaces \\
\hline & & Private spaces \\
\hline & Architectural Aesthetics & Form \\
\hline & & Surface \\
\hline & Use of scenery & Living space- scenery relationships \\
\hline \multirow{14}{*}{ 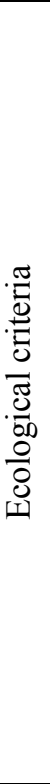 } & Orientation & Orientation towards the sun \\
\hline & Energy efficiency & Isolation \\
\hline & Comfort zones & Heat comfort \\
\hline & & Acoustic comfort \\
\hline & & Air comfort and ventilation \\
\hline & Solar Energy Use & Heating \\
\hline & & Energy generation \\
\hline & Wind Energy Use & Ventilation \\
\hline & & Energy generation \\
\hline & Contribution to recycling & Waste Management \\
\hline & Reduce water consumption & Water Management \\
\hline & \multirow[t]{2}{*}{$\begin{array}{l}\text { Use of recycled and } \\
\text { sustainable materials }\end{array}$} & Materials used in construction \\
\hline & & Materials used in finishings \\
\hline & $\begin{array}{c}\text { Use of shading elements to } \\
\text { prevent sun }\end{array}$ & $\begin{array}{l}\text { Shading element design in } \\
\text { southern-eastern-western windows }\end{array}$ \\
\hline
\end{tabular}

Evaluating test group students' design process and final works, students seem to be focused on orientation, energy efficiency, use of shading elements to prevent sun and photovoltaic panels to produce electricity (fig. 1). Inner courtyards are used in order to provide natural lighting to inner spaces (fig. 1). Most students focus on comfort zones in their projects. Natural ventilation is an important design criterion in some of the projects (fig. 2). For heating purposes trombe walls and solar rooms are used in some of the projects as seen in fig. 3 .

\subsubsection{Test and control group questionnaires and evaluations}

After the 3 weeks' work focusing on sustainable issues, a questionnaire is given out to students, and 23 of test group and 17 of control group questionnaires are 
collected back. The questionnaire is aimed to measure their awareness on the sustainable and ecological design issues, their process throughout the semester and to get overall opinions.
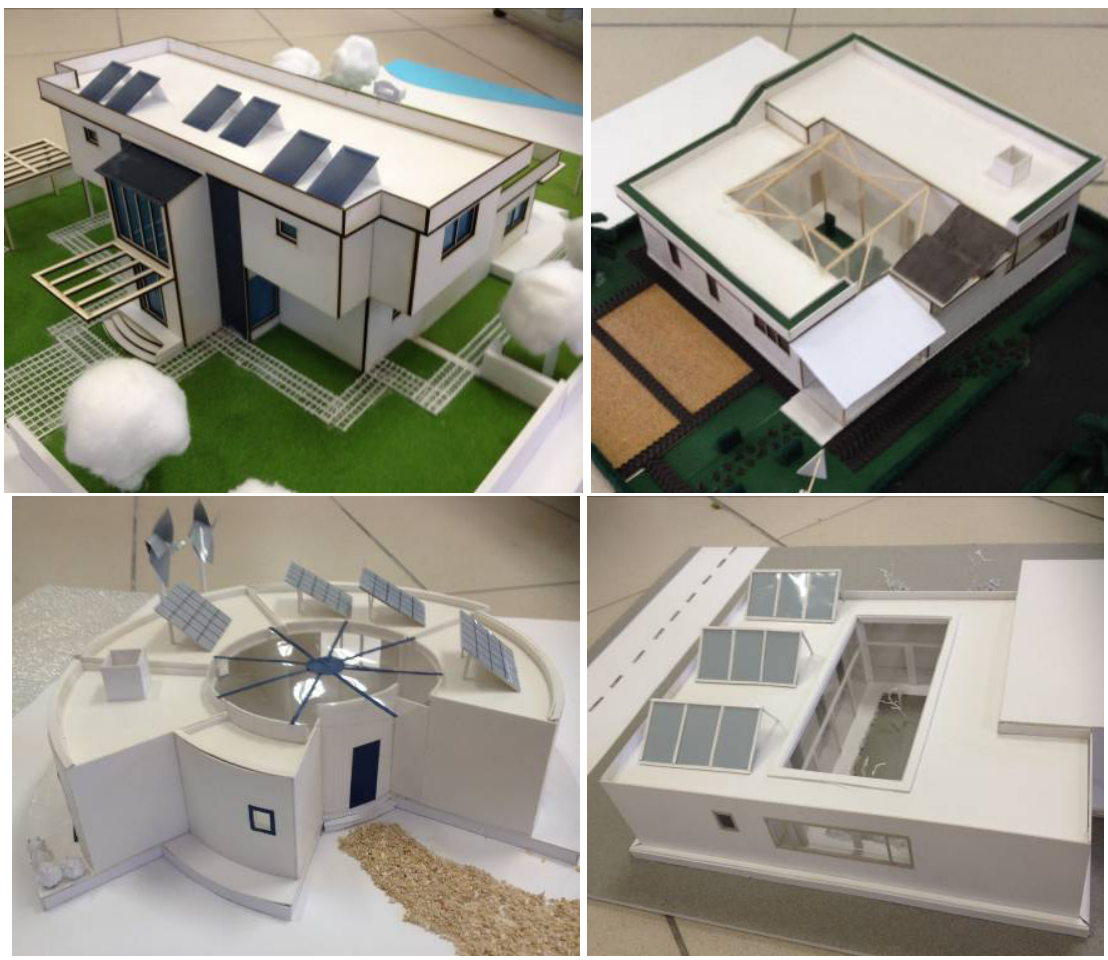

Figure 1: Models of the final house projects, test group students (upper left: Berkay Firat; upper right: İbrahim Nalbantoglu; bottom left: Seyma Hancer; bottom right: Sena Hardal).

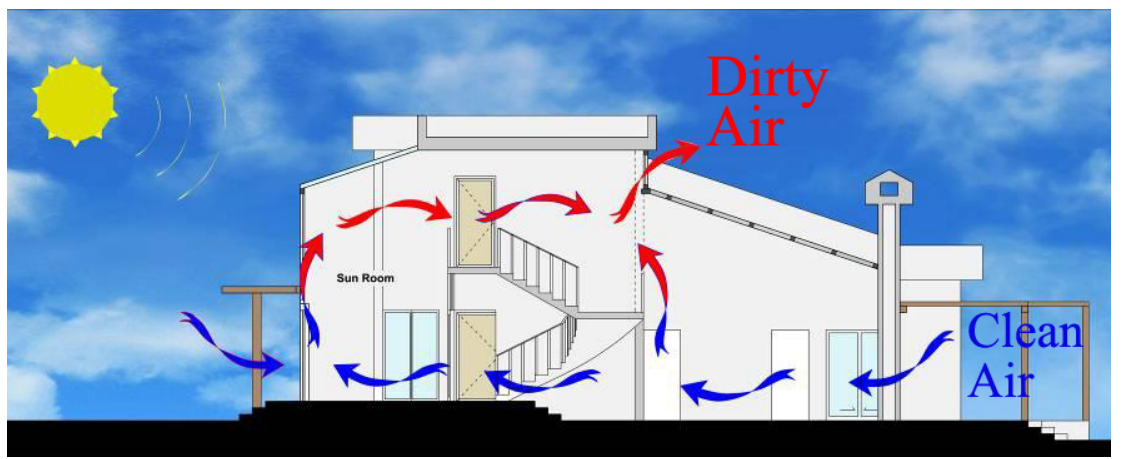

Figure 2: Section diagram of natural ventilation of a test group student (Berkay Firat). 


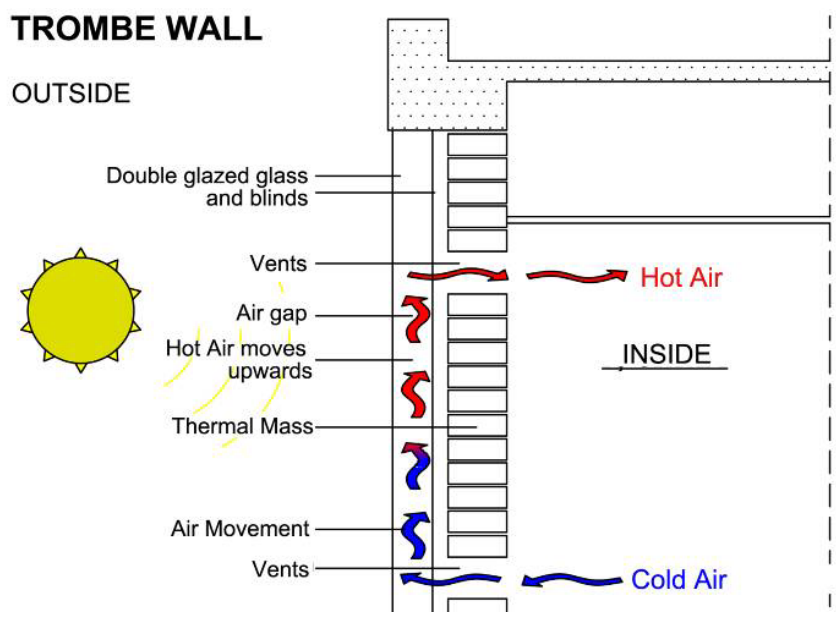

Figure 3: Trombe wall section diagram of passive heating of a test group student (Berkay Firat).

In the first section of the questionnaire, the questions are asked to evaluate their knowledge on basic design concepts. These are functional scheme, space layout, zoning, technical drawing skills, and green architecture. At the end, students are asked for an overall evaluation on their knowledge.

On the concept of functional scheme, the comparison shows us test group students are better than "totally agreed students" on the concept $-70 \%$ (test group-TG) to $47 \%$ (control group-CG). On the concept of space layout, TG students are better than "totally agreed students" - 52\% (TG) to $47 \%$ (CG). On the concept of zoning, TG students are better than "totally agreed students" $56 \%$ (TG) to $29 \%$ (CG). On the concept of technical drawing, TG students are better than "totally agreed students" - 48\% (TG) to $41 \%$ (CG). On the concept of green architecture, TG students are better than "totally agreed students and agreed students" - 87\% (TG) to 59\% (CG). On the overall evaluation, TG students are better than "totally agreed students and agreed students" $-87 \%$ (TG) to $76 \%$ (CG), as shown in tables 3 and 4.

Table 3: Evaluation of basic design concepts (TG, 23 students are evaluated).

\begin{tabular}{cccccc}
\hline \multicolumn{5}{c}{ Question: In house design, I have gained knowledge about "the following concepts" } \\
\hline & Totally agree & Agree & Neutral & Disagree & $\begin{array}{c}\text { Totally } \\
\text { disagree }\end{array}$ \\
\hline Functional scheme & 16 students $(70 \%)$ & $7(30 \%)$ & - & - & - \\
Space Layout & $12(52 \%)$ & $11(48 \%)$ & - & - & - \\
Zoning & $13(56 \%)$ & $8(35 \%)$ & $2(9 \%)$ & - & - \\
Technical drawing & $11(48 \%)$ & $11(48 \%)$ & $1(4 \%)$ & - & - \\
Green architecture & $5(22 \%)$ & $15(65 \%)$ & $3(13 \%)$ & - & - \\
\hline Overall evaluation & $6(26 \%)$ & $14(61 \%)$ & $3(13 \%)$ & - & - \\
\hline
\end{tabular}


Table 4: Evaluation of basic design concepts (CG, 17 students are evaluated).

Question: In house design, I have gained knowledge about "the following concepts"

\begin{tabular}{cccccc}
\hline & Totally agree & Agree & Neutral & Disagree & $\begin{array}{c}\text { Totally } \\
\text { disagree }\end{array}$ \\
\hline Functional scheme & 8 students & $9(53 \%)$ & - & - & - \\
$\begin{array}{c}(47 \%) \\
\text { Space Layout }\end{array}$ & $8(47 \%)$ & $9(53 \%)$ & - & - & - \\
$\begin{array}{c}\text { Zoning } \\
\text { Technical drawing }\end{array}$ & $5(29 \%)$ & $8(47 \%)$ & $4(24 \%)$ & - & - \\
Green architecture & $3(18 \%)$ & $10(59 \%)$ & - & - & - \\
\hline Overall evaluation & $4(23 \%)$ & $9(51 \%)$ & $6(35 \%)$ & $1(6 \%)$ & - \\
\hline
\end{tabular}

The results show us that basic design concepts and the awareness on these issues are improved as well as green architecture concepts in the test group. When students are introduced to environmental issues on architecture, their awareness and performance are raised.

\subsubsection{Comparative results}

In the questionnaire, students are asked to rank the architectural and ecological concepts from 1 to 13 , depending on their priorities when designing a house. Questionnaire results are compared between test and control groups, to show the architectural and ecological concept rankings (percentages) of the designed houses, table 5 .

Table 5: $\quad$ Rating of house design concepts.

\begin{tabular}{|c|c|c|c|c|c|}
\hline & \multicolumn{2}{|c|}{ Test Group (sec 6) } & \multicolumn{2}{|c|}{ Control Group (sec 5) } \\
\hline & & Ranking & Percentage & Ranking & Percentage \\
\hline \multirow{4}{*}{ 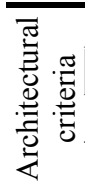 } & Functional use & 1 & $12,71 \%$ & 1 & $12,93 \%$ \\
\hline & Zoning & 2 & $11,61 \%$ & 3 & $10,28 \%$ \\
\hline & Architectural Aesthetics & 5 & $8,93 \%$ & 5 & $9,95 \%$ \\
\hline & Use of scenery & 6 & $8,41 \%$ & 2 & $12,22 \%$ \\
\hline \multirow{9}{*}{ 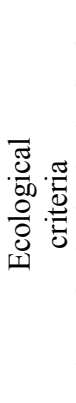 } & Orientation & 4 & $9,08 \%$ & 4 & $10,08 \%$ \\
\hline & Energy efficiency & 8 & $6,98 \%$ & 9 & $5,75 \%$ \\
\hline & Comfort zones & 7 & $7,31 \%$ & 10 & $5,56 \%$ \\
\hline & Solar energy use & 3 & $9,08 \%$ & 6 & $8,99 \%$ \\
\hline & Wind energy use & 9 & $6,31 \%$ & 8 & $5,82 \%$ \\
\hline & Contribution to recycling & 11 & $5,16 \%$ & 12 & $3,81 \%$ \\
\hline & Reduce water consumption & 13 & $4,40 \%$ & 13 & $3,49 \%$ \\
\hline & $\begin{array}{l}\text { Use of recycled and } \\
\text { sustainable materials }\end{array}$ & 10 & $5,54 \%$ & 11 & $5,11 \%$ \\
\hline & Use of shades to prevent sun & 12 & $4,49 \%$ & 7 & $6,01 \%$ \\
\hline
\end{tabular}

Ranking: 1 (most desired), 13 (less desired)

Percentage: Rate of selected concept vote to whole group votes. 
Therefore, positive results are described as followed:

"Zoning" concept is improved by rising from rank 3 to rank 2. Zoning is mentioned in both groups through the whole semester, but different sub themes are introduced. Since both groups are familiar and experienced in functional zoning, test group also develop their designs on zoning based on energy gains and sun path diagram.

"Energy efficiency" concept is improved by rising from rank 9 to rank 8. By this concept, basically isolation of walls and windows are discussed with test group. Since students are not familiar with technical details, they have just learned how important to isolate the buildings for energy efficiency. This concept is one of the most important issues for sustainability agenda.

"Comfort zones" concept is improved by rising from rank 10 to rank 7 . This concept includes thermal comfort, acoustic comfort and air quality. Most of test group students have become aware of ideal temperatures for human comfort in different spaces and how it can be achieved. Thermal comfort is the one that students focused more by placing spaces in proper directions, insulating walls and windows while using shading materials.

"Solar energy use" concept is improved by rising from rank 6 to rank 3. Some students in the control group have used sun for heating and natural lighting by placing south faced spaces in a passive way. Additionally test group students used sun energy by placing solar rooms and trombe walls in south facade, as well as photovoltaic panels for producing electricity and heating water.

"Contribution to recycling" concept is improved by rising from rank 12 to rank 11. Recycling is introduced mostly focusing on waste management. Recycling of materials such as plastic, paper, metals etc., collection and reuse of rain, grey and black water are discussed. Both groups have become aware of the importance of recycling.

"Reduce water consumption" concept is the same and the lowest at both groups. However, the percentage in the test group is higher than the control group therefore the test group have put more emphasis on this concept. A+ appliances such as dishwasher and washing machine, water taps with photocells are used to reduce water consumption.

"Use of recycled and sustainable materials" concept is improved by rising from rank 11 to rank 10. This is the concept that test group students questioned during the process. The materials used for rough and fine construction should be recycled, toxic free and environmentally friendly.

Since the test group is introduced with this new ecological and sustainable concepts at the end of the semester, the architectural themes that are focused for the whole semester became a secondary issue after all. The projects did not lose any quality but the students' priorities have changed. Therefore negative results are described as followed:

"Functional use", "orientation" and "architectural aesthetics" concepts are same in ranking but control group's percentage is higher. At the same time "use of scenery" concept is decreased from rank 6 to rank 2. These issues were the most important ones for both groups throughout the semester. But, at the end 
when sustainability issues are introduced to test group, their priorities have changed, which is also a positive result for this work.

\section{Results and conclusion}

Based on the evaluation of the questionnaires;

- Students are eager to study on ecological concepts, they enjoy and learn how to design an ecological house. They wish that ecological concepts were introduced earlier, so that they can develop their project more thoroughly.

- Students think that they are really "introduced" to architecture by this method, and their approach to sustainable issues were changed.

- Some students agree that it was surprising to be introduced new concepts in architecture which is not the case in their living environment. Recycling is the key issue to start thinking on our residential architecture again.

- It is possible to minimize the effects of a building in an environment, from scratch to the end.

- Making models in the design process helped them to understand the third dimension much better than technical drawings.

- Group presentations were so informative that they experience the worldwide projects by seeing and doing models.

- Students are "inspired" by the built ecological projects, these new concepts changed their point of view.

Based on overall results;

- Sustainability issues should be introduced as early as possible in order to educate skilled and knowledgeable architects.

- These concepts should be taught via case studies and sample projects by basic topics. Students should not be confused by complicated details.

It is important to be aware of the student level when introducing these concepts, not to bother them with too much technical detail. It is aimed to raise awareness on sustainability in architectural concepts, as in the famous proverb "you cannot teach an old dog new tricks". The results show us how important and necessary is to introduce these issues in basic design education.

\section{Acknowledgements}

We would like to thank Istanbul Aydin University for providing us with the studio environment; instructor Tansu Acimert for his contributions to the studio courses; and students for their invaluable work and enthusiasm.

\section{References}

[1] Arkun, N.S., Kaya I.S., Onbilgin, T.T., Sayar, Y., Aritan, O., Atilgan, D., Ocal, C., Mimar Adaylarina Temel Tasarim Egitiminde Uygulanan bir Program Uzerine Dusunceler", Mimarlik, 293, pp. 39-40, 2000. 
[2] Koester, R.J., Centers for Regenerative Studies: Graduate Studio Experiences in Education for Sustainable Design. Proc. of PLEA2006, Geneva, Switzerland, 1, pp. 659-664, 2006.

[3] Schön, D.A., Educating the Reflective Practitioner, New York: Basic Books, Inc. Publishers, pp. 105-106, 1985.

[4] Schön, D.A., The Design Studio: An Exploration of its Traditions and Potential, London: RIBA Pub. Ltd., pp. 70, 1987.

[5] Tabb, P., Rashed-Ali, H., Architecture Unplugged: The Teaching of the Principles, Needs and Calculation Procedures for Sustainable Housing Design. Proc. of PLEA, Geneva, Switzerland. 1, pp. 623-628, 2006.

[6] Yeang, K., Designing with Nature, The Ecological Basis for Architectural Design, McGraw Hill, USA pp. 1-16, 187-211, 1995.

[7] Hamza, N., Horne, M., Educating the designer: An operational model for visualizing low-energy architecture, Building and Environment, 42, pp. 3841-3871, 2007.

[8] Fuchs, H.U., Simon, M., Teaching building simulation with the help of general purpose dynamical modelling software. Proc. of the IBPSA Building Simulation conference, Madison, Wisconsin, USA, 362-369, 1995.

[9] Hensen, J., Hraska, J., Mallory-Hill, S., Rabenseifer, R., Introducing ITbased environmental simulation courses at Slovak Technical Universities, Environmentally Friendly Cities, Proc. of PLEA, Lisbon, Portugal, pp. 623626, 1998.

[10] Ozer, D.G., Utkutug, G., Bina Enerji Performans Simulasyonunun Mimari Tasarım Stüdyosuna Entegrasyonu, 1st International Graduate Research Symposium on the Built Environment, METU, Ankara, Turkey, vol.2, pp. 47-52, 2010.

[11] Yannas, S., Learning Environment, Proc. of PLEA, Geneva, Switzerland, 1, pp. 25-30, 2006.

[12] Roulet, C.A., Architectural Education for Sustainable Design, A Proposal for Improving Indoor Environment Quality, Proc. of PLEA, Geneva, Switzerland, 1, pp. 653-654, 2006.

[13] Ozer, D.G., Harmankaya, Z.Y., Energy Conscious Ecological Architecture Education in Architecture Departments of Turkey, International Sustainable Buildings Symposium (ISBS), 26-28 May, Ankara, Turkey, pp. 862-865, 2010.

[14] Radovic, D., Ecophilosophy and education in architecture, Environmentally Friendly Cities, Proc. of PLEA, Lisbon, Portugal, pp. 627-628, 1998. 